\title{
Peertechz
}

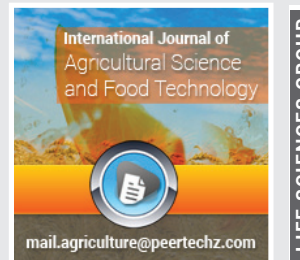

\section{Ecological situation of acacia tortilis subspecies raddiana. Case study: In white nile state,} \section{Sudan}

Received: 08 July, 2020

Accepted: 27 January, 2021

Published: 28 January, 2021

*Corresponding author: Abdelsami Musa Ibrahim Adam, Livestock Marketing and Resilience Programme, (LMRP)/IFAD, Sudan,

E-mail: abedokosti222221@gmail.com

Keywords: Acacia raddiana tree; White Nile State of Sudan; Dominance; Natural regeneration

https://www. peertechz.com

\section{Check for updates}

\author{
Goda MMB ${ }^{1}$, Dosougi MA², Osman A $^{3}$ and A Musa Ibrahim ${ }^{4 *}$ \\ ${ }^{1}$ Forest Extension, Forest National Corporation, Sudan \\ ${ }^{2}$ Dean of Forest Colleges, Sudan University for Science and Technology, Khartoum, Sudan \\ ${ }^{3}$ Forest Colleges, Sudan University for Science and Technology, Sudan \\ ${ }^{4}$ Livestock Marketing and Resilience Programme, (LMRP)/IFAD, Sudan
}

\begin{abstract}
This study conducted during the season 2017 at ED-Duem Locality which is laid at Northern White Nile State of Sudan, the main objectives of this study was measurement, listing of all acacia raddiana tree sites their assessed the physical characteristics of the height, diameter at breast height and were account the abundance, dominance, and survival \% of natural regeneration of acacia raddiana tree as the main species. The researcher used the systematic circular sampling plots methodology which established with total number of 130 sample plots. The sample plots were circular in shape with a radius of $17.84 \mathrm{~m}$ ( $0.1 \mathrm{ha}$ in area.). In these sample plots all trees with diameter at breast height ( $\mathrm{dbh}$ ) equal to or greater than seven centimeters were measured for tree species, and the regeneration survey in each sample plot (10) quadrats ( subplots) of $1 \mathrm{mx} 1 \mathrm{~m}\left(1 \mathrm{~m}^{2}\right)$, the regeneration survey in each sample plot (10) quadrats ( subplots) of $1 \mathrm{mx} 1 \mathrm{~m}\left(1 \mathrm{~m}{ }^{2}\right)$ were calculated. The results showed no significant different for acacia raddiana tree in eight sites, and the survival rate of Acacia raddiana regeneration are (20.4-23.9\%).
\end{abstract}

\section{Introduction}

The total forest cover in the Sudan before the separation of the country was 76381 ha in 1990 , decreased to 70491 ha in 2000 , and to 70220 ha in 2005, where it became 69949 ha in 2010; of this about 49891 ha $(71 \%)$ is known to be naturally regenerated forests. In general Sudan lost between 1990 and 2010 an average of $321.6 \mathrm{ha}, 0.42 \%$ per year which amount $8.4 \%$ of its forest covers [1]. White Nile State rich with vegetation types and many flora in natural forests, and as forest covers. Acacia raddiana tree is one of the flora in natural stands. The genus Acacia belongs to the family fabacease, and subfamily Mimosaceae. Acacia raddiana is synonyms Acacia raddiana. It is a gregarious tree and between $7-21 \mathrm{~m}$ in length [2]. The genus occurs in Sudan. The known species of the Sudan is Acacia raddiana, and the Arabic name of the tree is "Sayal". Eventually, Acacia species considered as one of the most important species in arid and semiarid areas and used widely in all the zones where it is ecologically adapted, water found in areas with maximum average rain < $600 \mathrm{~mm}$ Mustafa [3], Acacia tortilis subspecies raddiana occurs in the White Nile State in aggregates areas, it is the highest as it occurs in different area at Eldouim locality. Lamprey [4] found 7 percent natural germination from seed collected from faecal pellets. He obtained no regeneration of seed from fallen pods. At present, it regenerates in area frequented by animals (night holding grounds, round ponds and wells and in the neighborhood of villages), and also in areas newly opened to cultivation on which animals roam freely after harvest. Natural regeneration rates of $19-27 \%$ were obtained in Eritrea [5], considered as poor. The disadvantages of the natural regenerations are: Less control over initial stocking and spacing, generally lower commercial yield, no generic improvement or the introduction of disease resistant stock, possible delays in regeneration due to drought or inadequate ingested seeds and the possible need for precommercial thinning to ensure good growth. It is classified 
as a multipurpose tree, used as a browse tree for fattening animals during dry season, shade, green wall, energy, poles, popular medicine and pharmaceutical, one of groups of nontimber forest product like Gum is edible and can be used like Gum Arabic [6].

\section{Study area}

Study was carried out at White Nile State. The position between (13 5809.9 and 143022.5 North 320307.2 and 3202 15.8 East). The area of the White Nile State is almost 34567 ha. The total population of the state in 2009 was around 1730588, out of which $1149292(66.4 \%)$ live in rural areas. The main tribes living in the area are Hassania, Kowahalla, hussunate, Kababish, Magadai, and Galieen. The soil habitats are loamy or gravely soils as was indicated by Elamin [2]. The water resources include the White Nile River which is representing the main water source in the area, the underground water and the surface water including khors, wadies. The vegetation coverage is available according to the climatic zones. The study area is generally characterized by high temperatures for most of the year, with means of $37^{\circ} \mathrm{C}$ and $21^{\circ} \mathrm{C}$ for maximum and minimum summer temperatures respectively [7]. The rainy season extends from June to October and most of the rains fall during July to August. The average annual rain falls for Eldouim had declined from $330 \mathrm{~mm}(1920-1950)$ to $239 \mathrm{~mm}$ (1990-2012).

\section{Methodology}

\section{Assessment of tree species and natural regeneration}

Layout of sample plots: The systematic circular sampleplots [8] were used in this study. The area covered in this study was 258 hectares. 8 sites (camps) were selected and established with a total number of 130 sampleplots. The sampleplots were circular in shape with a radius of $17.84 \mathrm{~m}$ ( 0.1 ha in area). In these sample plots all acacia raddiana trees, and their natural regeneration which were measured and analyzed as follow:

\section{T- test at Acacia raddiana tree.}

Parameter assessment of the area: In each sampleplot tree were measured in different parameters, and data recorded for each tree. Acacia raddiana species identified (size and number); tree height in $\mathrm{m}$ and diameter at breast height (d.b.h), cm. data for each sampleplot recorded in a sheet. In each sampleplot the natural regeneration counted and recorded Acacia raddiana tree. Further the trees height was also classified into the height classes. Diameters were also classified in to the diameter classes., and in each sampleplot the natural regeneration was counted and recorded of acacia raddiana tree.

\section{Natural regeneration}

For assessment of natural regeneration in the study area, plots need to be small. These may be based on separate sampling or sub plots within conventional forest inventory plots [9].

The regenerating species (R.S.) were calculated and analyzed as follow:
Abundance, domance, and the survival rate for natural regeneration on Acacia raddiana tree.

Assessment of tree species and natural regeneration:

\section{Layout of sample plots}

The systematic circular sampleplots [8] were used in this study. The area covered in this study was 258 hectares. 8 sites (camps) were selected and established with a total number of 130 sampleplots. The sampleplots were circular in shape with a radius of $17.84 \mathrm{~m}$ ( 0.1 ha in area)., in these sampleplots all acacia raddiana trees, and their natural regeneration which were measured and analyzed as follow:

\section{T- test: Acacia raddiana tree}

In each sampleplot tree were measured in different parameters., and data recorded for each tree. acacia raddiana species identified (size and number); tree height in $\mathrm{m}$ and diameter at breast height (d.b.h), cm., data for each sampleplot recorded in a sheet. In each sampleplot the natural regeneration counted and recorded acacia raddiana tree. Further the trees height was also classified into the height classes. Diameters were also classified in to the diameter classes., and in each sampleplot the natural regeneration was counted and recorded of acacia raddiana tree.

\section{Natural regeneration}

For assessment of natural regeneration in the study area, plots need to be small. These may be based on separate sampling or sub plots within conventional forest inventory plots [9].

\section{The regenerating species (R.S.) were calculated and analyzed as follow}

Abundance, domance, and the survival rate for natural regeneration on Acacia raddiana tree.

\section{Results and discussion}

\section{Effect of Site on the average density /ha of Acacia torti- lis subspecies raddiana}

Table 1 shown the statistical analysis of no significant difference on Acacia raddiana tree in eight sites. The highest number of trees at taha Elbabonus site (one), may be attributed to continuous presence of forest guards, and communal settlement ("waara"). The lowest number of trees at Elshegig site (eight). trees varies in occurrence or frequency. Graph 1. Acacia raddiana tree occurs in 105 sample plots out of 130 sample plots. The test value is 86.25 which means the normal distribution q-q plot of number of trees. The average number of tree/ ha was about 53.31 trees in the eight sites of the study area, it considered very low, which indicates the deterioration. Elsefory [10] mentioned that the wood species was 19.3 stem/ ha at the three sites in the same study areas, which signalize the declination. Goda [11] calculated that the average of Acacia albida tree about 11 trees/ha in four sites at the study area, which point out retrogradation. 


\section{Height classes' distribution of Acacia tortilis subspecies raddiana}

Table 2, Figure 1 shows the distribution at Acacia raddiana of the height classes in ranges of $1.5-9.49 \mathrm{~m}$. The tree species is poorly represented in the small height class at sites 6,7 and 8 in addition to the class of $9.5-14.49 \mathrm{~m}$. The species is mainly confined to the medium class of 5.9-9.49 $\mathrm{m}$. with a percentage of $66 \%$, were less than $10 \mathrm{~m}$ height. This means these trees are still young as indicated in height class. The low percentage of the species at the class of 9.5-14.49 m. may reflect the excessive utilization of the tree by local community as other coming from outside the area either for local uses or investment. This could be clear in sites protected by people (1, 2, 3, 4 and 5). Trees in sites 5, 6 and 8 are covering the degrees of first and second ranges in the height classes where as mature, and over mature trees were disappeared, while other sites covering the whole ranges of height classes, this may indicates the adoptability of sites to trees for their develop more vertically, and this description also followed their distribution of diameter classes in Table 2.

\section{Diameter classes distribution of Acacia tortilis subspe- cies raddiana}

The diameter classes' distribution always not follows the trend of species distribution according to height classes by sorting diameter classes into three ranges as height classes. Most of Acacia raddiana confined to the small diameter class 7-15.9 cm., representing $86 \%$ and $12 \%$ for medium class $16-$ $31.9 \mathrm{~cm}$., while $2 \%$ for the height class $32-47.9 \mathrm{~cm}$. Table 3 , Figure 2. The distribution of diameter classes along locations showed different picture. The species shows decreasing trend from site 1 going to site 8 , which may indicate the effect of site characteristic on the horizontal growth of the tree species. Sites of the study area could be categorized into two groups according to the species representation in diameter classes. The first group include sites 1, 2, 3, and 7 where the tree species is almost represented in all diameter classes, and the second group includes sites 4, 5, 6, and 8.were also represented on

Table 1: Analysis of Acacia tortilis subspecies raddiana in eight sites.

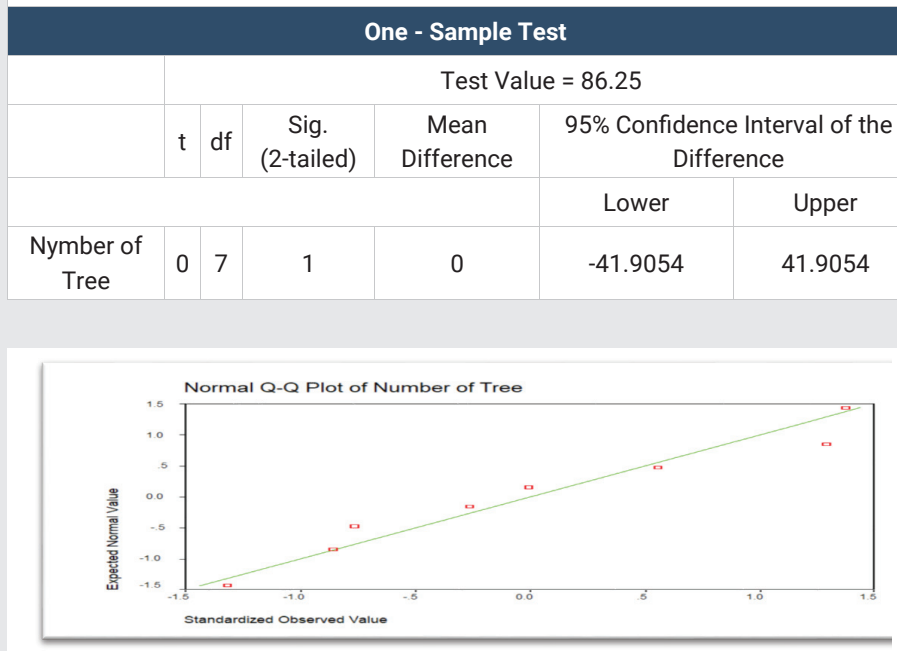

Graph 1: Normal distribution Q-Q plot of number of Acacia raddiana in eight sites.
Table 2: The number of Acacia tortilis subspecies raddiana trees in the different height classes $\mathrm{m}$.

\begin{tabular}{|c|c|c|c|c|c|c|c|c|c|c|}
\hline Range $(\mathbf{m})$ & Site1 & Site2 & Site3 & Site4 & Site5 & Site6 & Site7 & Site8 & Total & $\%$ \\
\hline $1.5-5.49$ & 74 & 46 & 41 & 20 & 33 & 1 & 5 & 2 & 222 & $32 \%$ \\
\hline $5.5-9.49$ & 86 & 104 & 69 & 51 & 45 & 42 & 44 & 19 & 460 & $66 \%$ \\
\hline $9.5-14.49$ & 1 & 3 & 4 & 2 & 0 & 0 & 1 & 0 & 11 & $2 \%$ \\
\hline Total & 161 & 153 & 114 & 73 & 78 & 43 & 50 & 21 & 693 & 100 \\
\hline
\end{tabular}

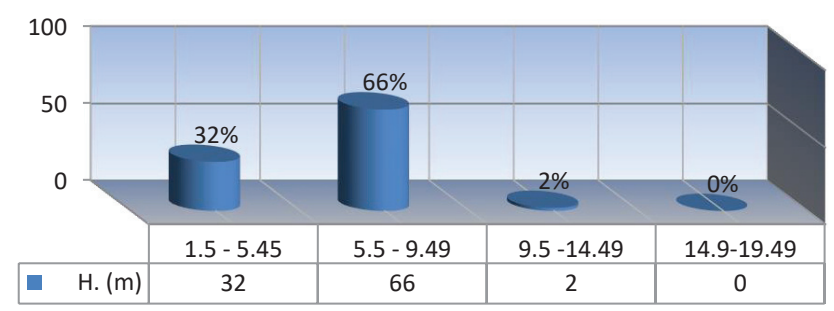

Figure 1: Height Calass ( $\mathrm{m})$ of Acacia raddiana sites.

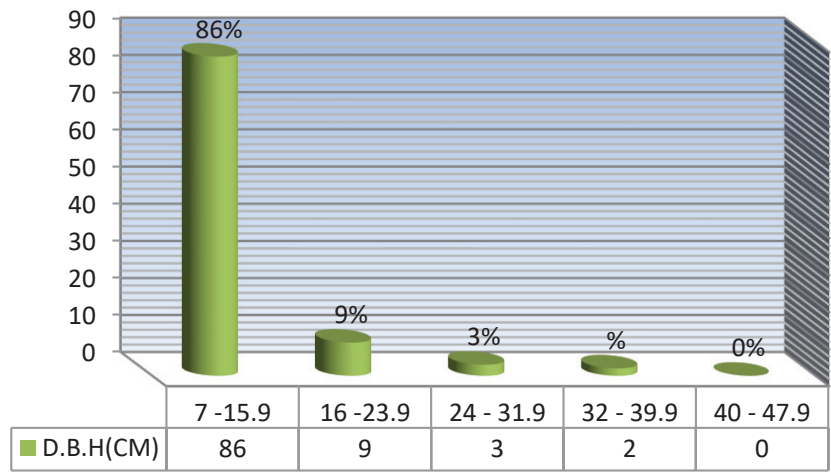

Figure 2: Diameter Classes $(\mathrm{cm})$ of Acacia raddiana Sites.

Table 3: Diameter classes (cm) for Diameter classes' distribution of Acacia tortilis subspecies raddiana trees sites.

\begin{tabular}{|l|l|l|l|l|l|l|l|l|l|l}
\hline DBH range cm & Site1 & Site2 & Site3 & Site4 & Site5 & Site6 & Site7 & Site8 & Total & $\%$
\end{tabular}

\begin{tabular}{|c|c|c|c|c|c|c|c|c|c|c|}
\hline $7-15.9$ & 156 & 126 & 100 & 56 & 78 & 23 & 39 & 20 & 598 & 86 \\
\hline $16-23.9$ & 1 & 19 & 5 & 12 & 0 & 20 & 4 & 1 & 62 & 9 \\
\hline $24-31.9$ & 3 & 5 & 5 & 5 & 0 & 0 & 4 & 0 & 22 & 3 \\
\hline $32-39.9$ & 1 & 3 & 3 & 0 & 0 & 0 & 3 & 0 & 10 & 2 \\
\hline $40-47.9$ & 0 & 0 & 1 & 0 & 0 & 0 & 0 & 0 & 1 & 0 \\
\hline Total & 161 & 153 & 114 & 73 & 78 & 43 & 50 & 21 & 693 & 100 \\
\hline
\end{tabular}

confined lower diameter classes. This gives another diameters on the effect on tree growth. All sites have little saplings, Acacia raddiana in less than seven centimeters were not available, this related with misuse of forest, and which disturbs the future presence of the species [12]. Gives some light for the reforestation and is managed good for fuel wood in natural woodlands in Sudan.

\section{Natural regeneration of Acacia tortilis subspecies rad- diana at eight sites}

The natural regeneration seeds at Acacia raddiana tree it is the matter of adequate conditions nearly in all Acacia raddiana 
sites. Natural regeneration of acacia raddiana were found in all sites with exception of site eight which were zero into the abundance, and also dominance per ha of July 2011, and survival rate in the same year were zero of acacia raddiana, Table 4. This site is unprotected after seed ripening and dispersal and the reasons may be the absence of guards and communal settlement "waara". The natural regeneration is quite promising in case of ingested seeds into "waara" ecology. The survival rate of natural regeneration of the species are (20.423.9\%), and Lamprey [4] found in Tarangere Game Reserve in Tanzania 7 percent germination from seed collected from faecal pellets. He obtained no germination of seed from fallen pods thus natural regeneration is very poor. Seedlings survival rates of $19-27 \%$ were obtained in Eritrea [5], considered as poor. This numbers of natural regeneration values are low as shown in Table 4. This is due to the seed losses their embryo , and inadequate ingested seed. Rainfall plays a vital role in natural regeneration in the Sudan. The density and occurrence of trees decreased northwards similar to pattern of rain fall. The natural regeneration from seeds is difficult on sites that receive less than $600 \mathrm{~mm}$, unless the seeds were ingested by animals or placed on flow sites. Mustafa [3] However, the natural regeneration number in 2011 was lower than in 2012. The reason may be due to the delay of rainfall in 30th of June in season 2011 while in 2012 than the rainfall started in the 13 the of June. And above all the total rains of 2011 to $210.8 \mathrm{~mm}$ at Eldouim Station compared to $385 \mathrm{~mm}$ in 2012 at the same station. But, in spite of all natural regenerations survival rate was almost similar in two seasons. It finds that high percentage of people poor as nomads in areas without guard, also no "waara" , and where nomads settle, with their livestock for a while, and after the rainy season the area is almost subjected to heavy grazing which causes by the intensive number of animals, which deteriorates the areas. Where there is Acacia raddiana regenerations, and a bit of regenerations (saplings) founds in the seven sites. Those locations are the only ones with guards, and "waara". Therefore, regenerations has chance to becomes mature trees if the sites are acceptable to the local community, and to be involved in the management and improvement of "waara" areas, which near to their villages, for their the natural benefits, and reforestation as the natural forest.

\section{Conclusion and recommends}

\section{Conclusion}

* The study indicates that there is no significant difference of Acacia raddiana tree in eight sites.
* The mature trees (in the height, and the diameter), probably disappeared.

* Acacia raddiana consider very low which indicates the deterioration.

* The highest number of trees in some sites resulted of regenerations through "waara" environments, and the continuous presence of forest guards.

* Acacia raddiana could regenerate naturally on "waara" area or in area frequented by animals.

* Natural regeneration rates of Abundance (Sep.2011. 6.75\%- Sep.2012. 9.13\%) were obtained in study areas, which is considered as very few and poor percentage.

* Sites of no the "waara" , and no guards, the Natural regeneration is difficultly.

* Some factors affecting regeneration are; trampling, rodents, children, fire regenerating and seeds harvesting by ants.

* The seeds are of three type's infested, empty and viable ones.

\section{Recommendation}

* Improves the management of forest programs.

* Grazing, and cultivation at Acacia raddiana sites, and as were always should be banned or at least regulated.

* There is a need for Forests National Corporation, integrated with local Communities and United Nation on rehabilitation the study area and other degraded lands.

* There is a need for Community Based Capacity Mechanism for awareness programs considering the importance of the trees species at the study areas, and other sites.

* Trees with diameter at breast height more than $23 \mathrm{~cm}$ can be used for harvesting seeds.

\section{References}

1. FAO (2010) Global Resources Assessment 2010. Main report FAO. Global Food and Agriculture Organization of the United Nations FAO. Forestry Paper 163. Rome 2010. Link: https://bit.ly/2YIVlaE

Table 4: Abundance, dominance and survival \% of natural regeneration of acacia tortilis subspecies raddiana in two seasons at eight sites.

\begin{tabular}{|c|c|c|c|c|c|c|c|c|c|c|}
\hline Site & Jul. 2011 & /ha & Sep.2011 & /ha & $\%$ Survival & Jul.2012 & /ha & Sep.2012 & /ha & $\%$ Survival \\
\hline 1 & 43 & 2048 & 12 & 571 & 27.91 & 55 & 2619 & 15 & 714 & 27.27 \\
\hline 2 & 41 & 1952 & 11 & 523 & 26.83 & 46 & 2190 & 13 & 619 & 28.26 \\
\hline 3 & 39 & 1957 & 9 & 429 & 23.08 & 42 & 2000 & 10 & 476 & 23.81 \\
\hline 4 & 31 & 1722 & 6 & 333 & 19.35 & 38 & 2111 & 14 & 778 & 36.84 \\
\hline 5 & 29 & 1833 & 7 & 467 & 24.14 & 32 & 2133 & 9 & 600 & 28.13 \\
\hline 6 & 24 & 2000 & 5 & 417 & 20.83 & 30 & 2500 & 8 & 667 & 26.67 \\
\hline 7 & 19 & 1583 & 4 & 333 & 21.05 & 26 & 2167 & 3 & 250 & 11.54 \\
\hline 8 & 0 & 0 & 0 & 0 & 0 & 11 & 1100 & 1 & 100 & 9.09 \\
\hline Mean & 28.25 & 1637 & 6.75 & 384 & 20.4 & 34.5 & 2103 & 9.13 & 526 & 23.95 \\
\hline
\end{tabular}


2. Elamin HM (1990) Trees and Shrubs of the Sudan. Ithaca press. 484. Link: https://bit.ly/2Mu8SQe

3. Mustafa AF (1997) Regeneration of Acacia seyal forests on the dry land of the Sudan clay plain. University of Helsinki 103. Link: https://bit.ly/2YiADOt

4. Lamprey (1967) City Data Forum > U.S Furm > Arizona, (Tree Threat (homes, Buy, Agriculture), Tarangire Game Reserve in Tanzania.

5. FAO (2002) Review and Synthesis on the state of knowledge of Boswellia species and commercialization of Frankincense in the dry lands of Eastern Africa. Rome. Italy.

6. Walker BH (1979) Game ranching in Africa. In: Walker BH (eds.). Management of Semi-Arid Ecosystems. Elsevier 55-81.

7. Halwagy R (1961) The vegetation of the Semi-Desert north-east of Khartoum Sudan. Oikos 12: 87-110. Link: https://bit.ly/3t2KV3B
8. Loetsch F, Haller KE (1973) Forest inventory. Vol. I München: BLV Verlagsgesellschaft.

9. FAO (1980) Forest volume estimate and yield predication. $V$ of 2-yield 22/2 Rome. Link: https://bit.ly/39l086o

10. Elsefory KA (2006) Eco-taxonomic study on the vegetation cover of Um rimmitta. White Nile State. Sudan. Ph.D. Diss. University of Khartoum. Sudan. Link: https://bit.ly/2M1AD34

11. Goda MM (2005) Ecology and importance of Faidherbia albida as browse tree in agro forestry systems at Zalingei area. Western Darfur State. Sudan. M.Sc. Degree. Sudan University of Science and Technology. Link: https://bit.ly/3qZ69gC

12. Bostid (1979) Tropical legumes: Resources for the future. National Academy of Sciences 331. Link: https://bit.ly/3iOOTYK
Discover a bigger Impact and Visibility of your article publication with Peertechz Publications

\section{Highlights}

* Signatory publisher of ORCID

* Signatory Publisher of DORA (San Francisco Declaration on Research Assessment)

* Articles archived in worlds' renowned service providers such as Portico, CNKI, AGRIS, TDNet, Base (Bielefeld University Library), CrossRef, Scilit, J-Gate etc.

* Journals indexed in ICMJE, SHERPA/ROMEO, Google Scholar etc.

* OAI-PMH (Open Archives Initiative Protocol for Metadata Harvesting)

* Dedicated Editorial Board for every journal

* Accurate and rapid peer-review process

* Increased citations of published articles through promotions

* Reduced timeline for article publication

Submit your articles and experience a new surge in publication services

(https://www.peertechz.com/submission).

Peertechz journals wishes everlasting success in your every endeavours.

Copyright: (c) 2021 Goda MMB, et al. This is an open-access article distributed under the terms of the Creative Commons Attribution License, which permits unrestricted use, distribution, and reproduction in any medium, provided the original author and source are credited.

Citation: Goda MMB, Dosougi MA, Osman A, Ibrahim AM (2021) Ecological situation of acacia tortilis subspecies raddiana. Case study: In white nile state, Sudan. J Agric Sc Food Technol 7(1): 043-047. DOI: https://dx.doi.org/10.17352/2455-815X.000086 